\title{
PERAN GAYA HIDUP TERHADAP KEPUTUSAN PEMBELIAN DI CAFE ORANGAE PUNCAK PADANJESE
}

\author{
Gio Fany Farela Hidayatullah \\ Dr. Zakiyah Zahara, SE.,MM \\ Program Studi S1 Manajemen, Fakultas Ekonomi, Universitas Tadulako \\ Email: giovanyfh@gmail.com,Zakiyah66.zm@gmail.com
}

\begin{abstract}
This research aims at finding out the influence of the lifestyle simultaneously and partially on the purchasing decision's at the Cafe Orange Puncak Padanjese. The research subjects were 60 respondent, with the sampling technique used is purposive sampling. The data were taken through questionnaire, observation, and interview. Multiple Regression Analysis model was used to analyze the data. The results show that: 1) Lifestyle that consisted of dimensions of activity, interest and opinion simultaneously gives significant influence on the decision in purchasing at Cafe Orange Puncak Padanjese. 2) Dimension of activity partially give significant influence on the decision in purchasing at Cafe Orange Puncak Padanjese. 3) Dimension of interest partially give significant influence on the decision in purchasing at Cafe Orange Puncak Padanjese. 4) Dimension of opinion partially give significant influence on the decision in purchasing at Cafe Orange Puncak Padanjese.
\end{abstract}

Keywords: Lifestyle, Activities, Interest, Opinion, Decision Purchasing.

\section{INTISARI}

Penelitian ini bertujuan untuk mengetahui peran gaya hidup secara simultan dan parsial terhadap konsumen dalam keputusan pembelian di Cafe Orange Puncak Padanjese. Subjek dalam penelitian ini adalah 60 responden, dengan teknik penarikan sampel yang digunakan adalah purposive sampling. Metode pengumpulan data dengan kuesioner, observasi dan wawancara. Analisis data menggunakan regresi linear berganda. Hasil penelitian menunjukkan: 1) Gaya hidup yang terdiri dari dimensi aktivitas, minat dan opini secara simultan memberikan pengaruh yang signifikan terhadap keputusan pembelian di Cafe Orange Puncak Padanjese. 2) Dimensi aktivitas secara parsial berpengaruh signifikan terhadap keputusan pembelian di Cafe Orange Puncak Padanjese. 3) Dimensi minat secara parsial berpengaruh signifikan terhadap keputusan pembelian di Cafe Orange Puncak Padanjese. 4) Dimensi opini secara parsial berpengaruh signifikan terhadap keputusan pembelian di Cafe Orange Puncak Padanjese.

Kata Kunci: Gaya Hidup, Aktivitas, Minat, Opini, Keputusan Pembelian

\section{Pendahuluan}

Era globalisasi saat ini banyak mempengaruhi perubahan perilaku gaya hidup manusia dalam beraktivitas dan peningkatan kebutuhan masyarakat. Peningkatan tersebut berdampak terhadap gaya hidup masyarakat yang semakin lama semakin meningkat, dimana gaya hidup manusia tidak terbatas baik dalam jenis maupun jumlahnya. Peningkatan kebutuhan memaksa perusahaan harus saling bersaing untuk mendapatkan pangsa pasar, berbagai strategi pemasaran ditawarkan untuk konsumen, untuk memancing minat konsumen lain terhadap produk yang ditawarkan. Bisnis kuliner saat ini sangat menarik perhatian, salah satu bisnis kuliner yang berkembang pesat saat ini adalah cafe. Cafe bagi masyarakat saat ini bukan hanya sebatas tempat makan tetapi juga untuk melepas penat mereka dalam beraktivitas seharian. Pada akhirnya mengikuti perkembangan zaman yaitu aktivitas dan kegiatan konsumsi menjadi sebagai salah satu kegiatan yang melibatkan gaya hidup. 
Gaya hidup yang berubah-ubah mendorong masyarakat untuk lebih selektif dalam memilih kebutuhan akan gaya hidupnya seperti halnya pada tempat makan yaitu cafe, gaya hidup menjadi salah satu faktor yang menjadi bahan perhatian dalam memutuskan pilihan pada cafe yang diputuskan untuk dikunjungi. Fenomena ini terlihat pada semakin maraknya konsumen mencari tempat makan yang lagi hits dan instagrammable. Salah satu cafe yang menjadi pilihan konsumen masyarakat saat ini adalah Cafe Orange Puncak Padanjese, cafe ini berdiri pada November 2017.

Berdasarkan hasil obeservasi awal penulis di Cafe Orange Puncak Padanjese, diperoleh gambaran bahwa umumnya konsumen datang ke cafe tersebut karena tempat yang disediakan cukup nyaman untuk bersantap dan menghabiskan waktu senggang dari kesibukan kerja mereka. Selain itu, cafe tersebut juga menyajikan konsep tempat yang bernuansa alam karena letak cafe ini berada diatas bukit yang tentunya dapat langsung melihat panorama kota palu yang sangat indah disaat malam hari sehingga pelangan yang berkunjung dapat menikmati makanan dan minuman dengan melihat pemadangan alam. Kelebihan lain dari cafe ini yaitu juga menyediakan fasilitas freewifi untuk pengunjung serta terdapat live music untuk menambah hiburan dan suasana nyaman bagi pengunjung.

\section{Kajian Literature Dan Pengembangan Hipotesis}

Kotler dan Keller (2009:5), pemasaran adalah proses setiap individu atau kelompok masyarakat mendapatkan kebutuhan dan keinginan dengan menciptakan penawaran serta bebas mempertukarkan produk dan jasa untuk orang lain. Manajemen pemasaran berperan secara krusial pada perusahaan, karena mengatur semua kegiatan pemasaran.

Kotler dan Keller (2009:5), manajemen pemasaran (marketing management) yaitu seni dan ilmu menentukan pasar sasaran dalam meraih, mempertahankan, meningkatkan pelanggan dengan menciptakan, menghantarkan serta mengkomunikasikan nilai pelanggan.

Menurut Kotler dan Keller (2009:160), perilaku konsumen yaitu bagaimana perilaku individu atau kelompok dalam memilih, membeli, menggunakan, barang jasa guna memuaskan keinginan.

Menurut Setiadi (2016:3) mendefinisikan perilaku konsumen adalah tindakan yang langsung terlibat dalam mendapatkan, mengonsumsi dan menghabiskan produk atau jasa, termasuk proses keputusan yang mendahuluinya.

Menurut Setiadi (2016:39), gaya hidup adalah kegiatan, minat dan opini seseorang (activities, interests, and opinios). Gaya hidup tidak menetap dan cepat berubah dalam diri. Gaya hidup dapat berubah dalam perkembangan zaman atau perubahan lingkungan sekitar.

Pengukuran gaya hidup metode Psikografik AIO menurut Sumarwan (2011:106), pengukuran mengenai gaya hidup dapat dilakukan dengan psikografik. Psikografik adalah suatu instrumen untuk mengukur gaya hidup, yang memberikan pengukuran kuantitatif dan bisa dipakai untuk menganalisis data yang sangat besar. Psikografik berarti menggambarkan psikologis konsumen. Psikografik sering diartikan sebagai pengukuran AIO (activity, interest, opinion), yaitu pengukuran kegiatan, minat dan pendapat konsumen.

Setiadi (2016:41) memaparkan ada beberapa indikator gaya hidup seseorang, yaitu:

1) Kegiatan (Activity) sesuatu hal yang dilakukan seseorang dilingkungan sekitar nya.

2) Minat (Interest) merupakan hal kegiatan yang disenangi dalam diri seseorang. Minat dapat mempengaruhikepribadian seseorang dalam aktivitasnya sehari-hari serta mempengaruhi keputusan pembelian.

3) Opini (Opinion) adalah pandangan konsumen dalam menanggapi berita yang beredar dilingkungan sekitar. Opini merupakan penafsiran, harapan dan evaluasi, seperti kepercayaan terkait maksud seseorang. 
Kotler dan Amstrong (2009:184), membeli produk alternatif atau produk pilihan. Dua faktor berada antara niat dan keputusan pembelian. Diantaranya, sikap orang lain dan situasional yang tidak diharapkan.

Tahap-tahap dalam proses pengambilan keputusan konsumen untuk membeli barang menurut Kotler dan Keller (2009:184-185) dibagi dalam lima tahapan seperti berikut ini:

a) Pengenalan Masalah

Menganalisa keinginan dan kebutuhan yang belum terpenuhi. Jika seseorang ingin sesuatu dalam hidupnya, ia akan berusaha untuk memenuhi kebutuhan.

b) Pencarian Informasi

Seseorang yang belum terpenuhi kebutuhan akan melakukan pencarian informasi yang bersifat aktif maupun pasif.

c) Evaluasi Alternatif

Menetapakan tujuan pembelian dengan menyeleksi produk-produk yang ada. Terkadang seseorang mencari sebuah produk tertentu namun produk atau kebutuhan yang dicari tidak dapat terpenuhi, sehingga seseorang akan mencari produk yang lain namun sejenis dengan melakukan penyeleksian dan penilaian terhadap produk yang ada.

d) Keputusan Pembelian

Keputusan yaitu proses membeli atau tidak sesudah melakukan beberapa tahapan. Jika konsumen membeli, harus menentukan keputusan yang harus diambil menyangkut jenis produk, merek, penjual, kuantitas, waktu pembelian dan cara pembayarannya.

e) Perilaku Pasca Pembelian

Sesudah membeli produk, konsumen dapat merasa puas atau tidak. Pemasar harus memantau kepuasan, tindakan dan pemakaian produk pascapembelian.

Cafe merupakan istilah yang berasal dari bahasa Perancis, yaitu coffe, dalam bahasa Indonesia kopi atau coffehouse, istilah tersebut muncul pada abad ke 18 di Inggris. Kopi pertama kali masuk ke Eropa pada tahun 1669 ketika utusan Sultan Mohammed IV yang berkunjung ke Perancis dengan membawa berkarung-karung biji misterius yang nantinya di kenal dengan nama coffe.Penyebaran Cafe di Eropa melalui jalur perdagangan, ke wilayah Italia dengan sebutan Caffe.Tahun 1839 muncul kata cafetaria dalam bahasa Amerika berasal dari bahasa Mexican Spanish. Awalnya cafe hanya kedai kopi, tetapi seiring waktu digunakan untuk makan malam(dinner).

Menurut Budiningsih (2009:51) cafe yaitu restoran kecil di luar hotel. Pilihan makanan terbatas namun tersedia minuman sejenis bir, soft drink, teh, kopi, cemilan dan lainnya.

Menurut Soenarno (2003:66) Cafe adalah restoran dengan menu terbatas. Cafe atau Coffee Shop yaitu tempat yang menyediakan menu cepat dan sederhana serta menyediakan minuman ringan untuk orang santai

Berdasarkan uraian diatas,cafe merupakan tempat bersantai, dimana pengunjung dapat memesan minuman dan makanan. Cafe saat ini tidak juga menyediakan makanan dan minuman namun memberikan hiburan seperti live music yang bertujuan untuk memberikan kenyamanan dan suasana yang rileks.

Dengan mengetahui gaya hidup konsumen, akan menjadi peluang bagi pemasar untuk menciptakan produk yang memberikan jasa yang sesuai sehingga konsumen dalam menentukan keputusan pembelian merasa puas dengan tempat yang menjadi pilihannya tersebut. Artinya ketika konsumen menyatakan tingkat kesukaan nya atau ketertarikannya terhadap tempat tersebut (cafe) maka ia akan memutuskan melakukan pembelian disana bahkan memberikan opini yang baik juga kepada pelanggan lainnya. Menurut pernyatan diatas dapat disimpulkan bahwa terdapat keterkaitan antara gaya hidup terhadap keputusan pembelian. 


\section{Keterkaitan Antara Variabel Gaya Hidup dan Keputusan Pembelian}

Gaya hidup menurut Kotler dan Keller (2012:192), merupakan pola hidup seseorang di dunia yang dikeluarkan pada aktivitas, minat, dan opininya. Dalam gaya hidup mencerminkan bagaimana orang tersebut dapat menghabiskan waktu dan uangnya yang dapat dilakukan dengan aktivitas, minat maupun pendapat-pendapat atau opini. Dalam aktivitas biasanya seseorang cenderung melakukan pembelian karena adanya pekerjaan, waktu senggang, kegiatan maupun mencari hiburan semata. Minat dalam keputusan pembelian berperan penting seperti, dorongan keluarga untuk berlibur dan rekreasi bersama. Selain itu, opini juga berpengaruh untuk seseorang melakukan keputusan pembelian seperti, pendapat terkait tempat yang nyaman dan sesuai dengan kebutuhan atau keinginan.

Hal tersebut dapat menjadi pemicu konsumen untuk melakukan pembelian akan semakin besar, dengan demikian gaya hidup mempunyai peran penting terhadap keputusan pembelian di Cafe Orange Puncak Padajese. Adapun hasil penelitian yang dilakukan oleh D Nata Wijaya (2018), mengungkapkan gaya hidup dan motivasi sangat berpengaruh signifikan terhadap keputusan pembelian.

\section{Hipotesis}

1 Gaya hidup yang terdiri dari demensi aktivitas, minat dan opini secara serempak berpengaruh signifikan terhadap keputusan pembelian padaCafe Orange Puncak Padanjese.

2 Aktivitas berpengaruh signifikan terhadap keputusan pembelian pada Cafe Orange Puncak Padanjese.

3 Minat berpengaruh signifikan terhadap keputusan pembelian pada Cafe Orange Puncak Padanjese.

4 Opini berpengaruh signifikan terhadap keputusan pembelian pada Cafe Orange Puncak Padanjese.

\section{Metode Penelitian}

Jenis penelitian ini adalah deskriptif kausal. Menurut Sugiyono (2016:11) deskriptif yaitu penelitian yang dilakukan guna mengetahui variabel mandiri satu atau lebih tanpa perbandingan atau menghubungkan variabel lain. Menurut Sugiyono (20016:12), hubungan kausal adalah hubungan sebab akibat, $\mathrm{X}$ mempengaruhi $\mathrm{Y}$ atau bila $\mathrm{X}$ maka $\mathrm{Y}$. Oleh karena penelitian ini berusaha menjabarkan hasil penelitian dari peran atau pengaruh variabel independen (X) yaitu gaya hidup diantaranya aktivitas $\left(\mathrm{X}_{1}\right)$, minat $\left(\mathrm{X}_{2}\right)$ dan opini $\left(\mathrm{X}_{3}\right)$ terhadap variabel dependen $(\mathrm{Y})$, yaitu keputusan pembelian padaCafe Orange puncak Padanjese. Objek penelitian ini adalah "Peran Gaya Hidup terhadap Keputusan Pembelian. Subjek penelitian ini adalah pengunjung cafeorange puncak padanjese.

Penelitian ini menggunakan 4 variabel penelitian dengan jumlah minimal sampel adalah 40 (40x10). Peneliti menggunakan sampel sebanyak 60 (15x4), sehingga memenuhi dari jumlah minimal sampel. Teknik penarikan sampel penelitian ini adalah purposive sampling. Menurut Sugiyono (2016:98) purposive sampling merupakan teknik pengambilan sampel dengan kriteria tertentu, misalnya orang tersebut mengetahui tentang apa yang kita harapakan sehingga akan mempermudah peneliti

Metode pengumpulan data yang digunakan dalam penelitian ini adalah: 
1. Observasi dilakukan dengan mengamati proses terjadinya beberapa kegiatan yang sedang berlangsung di lokasi penelitian dan kemudian dilakukan pencatatan.

2. Wawancara, yaitu metode dengan tanya jawab secara singkat dengan responden dan pemilik CafeOrange Puncak Padanjese. Adapun isi wawancara yang akan diajukan kepada responden mengenai pelayanan yang diberikan kepada pelanggan selama menjadi pelanggan CafeOrange Puncak Padanjese, sedangkan wawancara yang diajukan kepada pemilik Cafe, yaitu tentang deskripsi CafeOrange Puncak Padanjese meliputi profil singkat, visi dan misi, struktur organisasi dan jumlah karyawan.

3. Kuesioner, teknik pengumpulan data dengan memberikan daftar pertanyaan untuk diisi responden yaitu pelanggan yang pernah berkunjung di CafeOrange Puncak Padanjese.

\section{Analisis Regresi Linear Berganda}

Metode yang digunakan adalah Analisis Regresi Linear Berganda yang bertujuan memperlihatkan ada tidaknya hubungan fungsional antara dua variabel atau lebih. Model persamaan Regresi Linear Berganda yang digunakan dalam penelitian ini menurut Sugiyono (2016:243).Rumus dasarnya digambarkan sebagai berikut:

$$
Y=a+b_{1} X_{1}+b_{2} X_{2}+\ldots \ldots . .+b n X n+e
$$

Apabila rumus tersebut diaplikasikan kedalam penelitian ini, maka regresi linear berganda dengan formula sebagai berikut:

$$
\mathbf{Y}=\mathbf{a}+\mathbf{b}_{1} \mathbf{X}_{1}+\mathbf{b}_{2} \mathbf{X}_{2}+\mathbf{b}_{3} \mathbf{X}_{3}+\mathbf{e}
$$

Dimana:

$\mathrm{Y}=$ Keputusan pembelian Cafe Orange Puncak Padanjesse

$\mathrm{X} 1=$ Aktivitas

$\mathrm{X} 2=$ Minat

$\mathrm{X} 3=$ Opini

a $\quad=$ Nilai konstan atau tetap, yang merupakan rata rata nilai $\mathrm{Y}$ pada nilai

$\mathrm{X} 1, \mathrm{X} 2, \mathrm{X} 3$ sama dengan nol

$\mathrm{b}_{1}-\mathrm{b}_{\mathrm{n}} \quad=$ Koefisien regresi parsial

$\mathrm{e} \quad=$ Kesalahan Pengganggu

1. Pengujian Hasil Determinasi Ganda (Uji F)

a. Probability (sig-F) $\leq \alpha=0,05$ (pada tingkat kepercayaan 95\%), maka terbukti semua variabel independen $(\mathrm{X} 1, \mathrm{X} 2, \mathrm{X} 3)$ yang diamati secara serempak berpengaruh signifikan terhadap variabel dependen $(\mathrm{Y})$, dengan demikian hipotesis yang diajukan diterima kebenarannya.

b. Probability (sig-F) $\leq \alpha=0,05$ (pada tingkat kepercayaan 95\%), maka terbukti semua variabel independen $(\mathrm{X} 1, \mathrm{X} 2, \mathrm{X} 3$ ) yang diamati secara serempak tidak berpengaruh signifikan terhadap variabel dependen (Y), dengan demikian hipotesis yang diajukan ditolak kebenarannya.

2. Pengujian Hipotesis Determinasi Parsial (Uji t)

Jika probability (Sig-t) $\leq \alpha=0,05$, atau tingkat kepercayaan 95\%, maka terbukti bahwa semua variabel independen yakni kualitas layanan yaitu aktivitas $\left(\mathrm{X}_{1}\right)$, minat $\left(\mathrm{X}_{2}\right)$, opini $\left(\mathrm{X}_{3}\right)$, tidak berpengaruh signifikan terhadap variabel dependen yaitu keputusan pembelian (Y), dengan demikian hipotesis yang diajukan ditolak kebenaranya. 


\section{Hasil Dan Pembahasan}

Pengukuran kehandalan butir pernyataan kuesioner pada responden, hasil skor dihitung besar korelasinya antara score jawaban dengan bantuan SPSS. Uji validitas dan reliabilitas dilakukan pada pelanggan yang melakukan pembelian di Cafe Bukit Wisata Tadulako dengan jumlah sampel sebanyak 20 responden, guna mengetahui setiap indikator yang dituangkan dalam kuesioner layak atau tidak digunakan untuk penelitian.

\section{Hasil Uji Analisis Regresi Linear Berganda}

Penelitian ini menggunakan Analisis Regresi Linear Berganda dengan tujuan untuk menguji peran gaya hidup terhadap keputusan konsumen dengan tingkat kepercayaan 95\% dan tingkat signifikan $(\alpha \leq 0.05)$. Nilai signifikansi yang diperoleh apabila lebih kecil dari tingkat signifikan, maka nilai tersebut dapat dikatakan berpengaruh signifikan, adapun perhitungan statistik dalam penelitian ini menggunakan program SPSS 21. Lebih jelasnya hasil analisis Regresi Linear Berganda dapat dilihat pada Tabel 3 berikut:

Tabel 3

Hasil Uji Analisis Regresi Linear Berganda

\begin{tabular}{|c|c|c|c|c|c|}
\hline \multicolumn{5}{|c|}{ Dependen Variabel Y = Keputusan Konsumen } \\
\hline \multirow{2}{*}{$\begin{array}{c}\text { Variabel } \\
\text { Indenpenden }\end{array}$} & $\begin{array}{c}\text { Unstandardized } \\
\text { Coefficients }\end{array}$ & $\begin{array}{c}\text { Standardized } \\
\text { Coefficients }\end{array}$ & \multirow{2}{*}{ T } & Sig \\
\cline { 2 - 5 } & $\mathbf{B}$ & $\begin{array}{c}\text { Std. } \\
\text { Error }\end{array}$ & Beta & & 0,000 \\
\hline (Constant) & 1,306 & 0,300 & & 4.335 & 0,038 \\
\hline Aktivitas & 0,121 & 0,057 & 0,180 & 2.130 & 0,048 \\
\hline Minat & 0,167 & 0,083 & 0,177 & 2.019 & 0,048 \\
\hline Opini & 0,432 & 0,054 & 0,651 & 7.996 & 0,000 \\
\hline $\begin{array}{c}\text { Multiple R } \\
\text { R Square }\end{array} \mathbf{= 0 , 8 5}$ \\
$=\mathbf{0 , 7 2 2}$
\end{tabular}

Sumber: Data diolah tahun 2019

Dimana :

$$
Y=1,306+0,121 X_{1}+0,167 X_{2}+0,432 X_{3}+e
$$

1. A (constanta) adalah 1,306 yang artinya jika aktivitas $\left(\mathrm{X}_{1}\right)$, minat $\left(\mathrm{X}_{2}\right)$ dan opini $\left(\mathrm{X}_{3}\right)$ bernilai 0, maka keputusan pembelian pada Cafe Orange Puncak Padanjese tetap positif yaitu 1,306.

2. Nilai koefisien Regresi dimensi aktivitas $\left(b_{1}\right)$ bernilai positif yaitu 0,121 . Hal ini menyatakan bahwa apabila nilai aktivitas meningkat, maka akan diikuti oleh peningkatan keputusan pembelian padaCafe Orange Puncak Padanjese. 
3. Nilai koefisien regresi dimensi minat $\left(b_{2}\right)$ bernilai positif yaitu 0,167 . Hal ini menyatakan bahwa apabila nilai minat meningkat, maka akan diikuti oleh peningkatan keputusan pembelian padacafe Orange Puncak Padanjese.

4. Nilai koefisien regresi dimensi opini $\left(b_{3}\right)$ bernilai positif yaitu 0,432 . Hal ini menyatakan bahwa apabila nilai opini meningkat, maka akan diikuti oleh peningkatan keputusan pembelian padacafe Orange Puncak Padanjese.

5. $\quad R$ Square adalah koefisien determinasi, yang menunjukkan persentase sumbangan variabel independen terhadap variabel dependen. Nilai $R$ Square pada penelitian ini adalah 0,722 yang artinya persentase sumbangan pengaruh variabel aktivitas, minat dan opini terhadap keputusan pembelian padaCafe Orange Puncak Padanjese sebesar $72,2 \%$ sedangkan sisanya sebesar $27,8 \%(100 \%-72,2 \%)$ dipengaruhi oleh variabel lain yang tidak dimasukkan dalam penelitian ini.

6. Nilai koefisien korelasi $\mathrm{R}$ adalah 0,850 . Nilai $\mathrm{R}$ berkisar antara 0 sampai 1 , jika mendekati 0 maka hubungan semakin lemah. Nilai $R$ yang diperoleh dalam penelitian ini adalah 0,850 yang artinya hubungan atau korelasi antara variabel aktivitas, minat dan opini terhadap keputusan pembelian di Cafe Orange Puncak Padanjese sangat kuat, seperti yang dikemukakan oleh Sugiyono (Wahyono, 2013:89) sebagai berikut:

\section{Hasil Pengujian Hipotesis Secara Serempak (Uji F)}

Berdasarkan hipotesis pertama adalah untuk mengetahui keputusan konsumen yang terdiri dari aktivitas, minat dan opini berpengaruh signifikan terhadap keputusan pembelian pada Cafe Orange Pucak Padanjese. Hasil nilai regresi tersebut dapat diketahui bahwa nilai $F_{\text {hitung }}$ adalah 48,481 dengan tingkat signifikan 0,000 sedangkan $F_{\text {tabel }}$ pada taraf kepercayaan $95 \%(0,05)$ adalah 2,77 . Pada kedua perhitungan $F_{\text {hitung }}$ sebesar $>F_{\text {tabel }}$ dan signifikansinya $0,000>0,05$, sehingga hipotesis diterima. Hasil tersebut berarti terdapat pengaruh secara serempak pada variabel gaya hidup yang terdiri dari aktivitas, minat dan opini terhadap keputusan pembelian pada Cafe Orange Puncak Padanjese di Kota Palu.

\section{Hasil Pengujian Hipotesis Secara parsial (Uji t)}

Hasil pengujian secara parsial untuk setiap variabel independen terhadap variabel dependen dapat dilihat dari penjelasan berikut:

1. Variabel Aktivitas

Berdasarkan tabel 3, hasil pengujian SPSS diperoleh hasilangka signifikansi sebesar 0,038. Angka $0,038 \leq 0,05$ (nilai alpha) oleh karena itu, hipotesis diterima. Hasil ini berarti terdapat pengaruh signifikan variabel aktivitas terhadap keputusan pembelian pada Cafe Orange Puncak Padanjese.

2. Variabel Minat

Berdasarkan tabel 3, hasil pengujian SPSS diperoleh angka signifikan sebesar 0,48. Angka 0,048 $\leq$ 0,05 (nilai alpha) oleh karena itu, hipotesis diterima. Hasil ini berarti terdapat pengaruh signifikan variabel minat terhadap keputusan pembelian pada Cafe Orange Puncak Padanjese.

3. Variabel Opini

Berdasarkan tabel 3, hasil pengujian SPSS diperoleh angka signifikansi sebesar 0,000. Angka 0,000 $\leq 0,05$ (alpha) oleh karena itu, hipotesis diterima. Hasil ini berarti terdapat pengaruh signifikan variabel opini terhadap keputusan pembelian pada Cafe Orange Puncak Padanjese.

\section{Pembahasan Hasil Penelitian}

Berdasarkan hasil pengujian regresi linear berganda menunjukkan bahwa variabel gaya hidup yang terdiri dari aktivitas, minat dan opini secara serempak berpengaruh signifikan terhadap keputusan 
pembelian di Cafe Orange Puncak Padanjese. Gaya hidup terkait bagaimana konsumen memikirkan dirinya serta menghabiskan waktu dengan lingkungannya. Selain itu, mencerminkan pola konsumsi yang mengambarkan pilihan seseorang menggunakan uang dan memanfaatkan waktu yang dilakukan. Pernyataan ini membuktikan semakin tinggi tingkat gaya hidup konsumen ketika mengeluarkan sejumlah pendapatannya untuk berkunjung dan melakukan pembelian di Cafe Orange Puncak Padanjese maka keputusan pembelian akan semakin meningkat juga.

Konsumen dalam penelitian ini berkunjung dan melakukan pembelian di Cafe Orange Puncak Padanjese dikarenakan beberapa indikator yang berperan dalam setiap dimensi, diantaranya pernyataan; saya berkunjung di Cafe Orange Puncak Padanjese dalam memanfaatkan waktu senggang, momen keindahan di Cafe Orange Puncak Padanjese bersama keluarga serta mendapatkan informasi dari lingkungan sekitar saya mengenai Cafe Orange Puncak Padanjese. Pernyataan tersebut menjadi penunjang gaya hidup konsumen dalam pengambilan keputusan pembelian. Manfaat jika memahami gaya hidup konsumen yaitu pemasar dapat menggunakan variabel gaya hidup dalam mengembangkan produk sesuai dengan tuntutan gaya hidup konsumen.

Hasil penelitian ini juga didukung penelitian-penelitian terdahulu, salah satunya penelitian yang dilakukan oleh Ivana Chaterina (2016), dengan penelitian berjudul Pengaruh Gaya Hidup dan Harga terhadap Keputusan Pembelian Konsumen E'Chick (Studi Kasus Pada Mahasiswa Program Pendidikan Manajemen Bisnis Universitas Ciputra Surabaya). Hasil penelitian menunjukkan bahwa variabel gaya hidup berpengaruh positif dan signifikan terhadap keputusan pembelian. Penelitian ini juga sejalan dengan penelitian yang dilakukan oleh D Nata Wijaya, dkk (2018), dengan penelitian berjudul Pengaruh Gaya Hidup dan Motivasi terhadap Keputusan Pembelian (Survey pada Konsumen Starbuck, Kota Malang), (Studi Kasus Pada Mahasiswa Fakultas Ilmu Administrasi Universitas Brawijaya Malang). Hasil penelitian menunjukkan bahwa variabel gaya hidup berpengaruh signifikan terhadap keputusan pembelian.

\section{PENUTUP}

Berdasarkan uraian hasil penelitian dan pembahasan yang telah dilakukan, maka dapat ditarik beberapa kesimpulan, yaitu sebagai berikut:

1. Gaya hidup yang terdiri dari dimensi aktivitas, minat dan opini secara serempak berpengaruh signifikan terhadap keputusan pembelian di Cafe Orange Puncak Padanjese.

2. Dimensi aktivitas berpengaruh signifikan terhadap keputusan pembelian di Cafe Orange Puncak Padanjese.

3. Dimensi minat berpengaruh signifikan terhadap keputusan pembelian di Cafe Orange Puncak Padnajese.

4. Dimensi opini berpengaruh signifikan terhadap keputusan pembelian di Cafe Orange Puncak Padanjese.

Berdasarkan uraian kesimpulan di atas, maka ada beberapa hal yang dapat direkomendasikan kepada pihak-pihak terkait dengan penelitian ini diantaranya adalah sebagai berikut:

1. Kepada pemilik Cafe Orange Puncak Padanjese diharapkan untuk terus meningkatkan dan memberikan suasana yang nyaman bagi pelanggan, serta lebih mengutamakan kepuasan pelanggan.

2. Kepada peneliti selanjutnya yang meneliti mengenai judul yang sama, diharapkan dapat menambah variabel-variabel lain serta lebih mengeksplor item dan faktor yang tidak disebutkan dalam penelitian ini agar hasil yang didapatkan lebih maksimal. 


\section{REFERENSI}

Budiningsih, Asri, 2009. Belajar dan Pembelajaran, Rineka Cipta, Jakarta.

Chaterina, Ivana, 2016. Pengaruh Gaya Hidup terhadap Keputusan Pembelian Konsumen E'Chick. Jurnal Manajemen dan Start-Up Bisnis, 1 (3), 339-348.

Ghozali, Imam, 2013. Aplikasi Analisis Multivariate dengan Program IBM SPSS 21Update PLS Regresi, Badan Penerbit Universitas Diponegoro, Semarang.

Kotler, Philip dan Kevin Lane Keller, 2009. Manajemen Pemasaran. Edisi 13. Jilid 1 dan 2, Erlangga, Jakarta.

Setiadi Nugroho J, 2016. Perilaku Konsumen Konsep dan Implikasi untuk Strategi danPenelitian Pemasaran, 1 st.ed, Prenada Media, Jakarta.

Sugiyono, 2016. Metode Penelitian Kuantitatif Kualitatif dan Kombinasi (Mixed Methods), Alfabeta, Bandung.

Wijaya, D Nata., Sunarti dan Pangestuti, Edriana, 2018. Pengaruh Gaya Hidup dan Motivasi terhadap Keputusan Pembelian (Survei pada Konsumen Starbucks, Kota Malang). JurnalAdministrasi Bisnis, 55 (2), 75-83. 